\title{
Work Related Musculoskeletal Disorders in Electrical, Telecommunication and Instrument Mechanics of Armed forces
}

\author{
Roli D', Ali I', Neekhra V' \\ ${ }^{1}$ Sunadan Divatia School of Science, NMIMS, Mumbai, India \\ ${ }^{2}$ Det BWG (Q) Mumbai 400067, India
}

\section{ABSTRACT}

Introduction: Modern defence system has a significant role of electrical, electronic and instrument technicians in armed forces. Despite their intensive role, little is known about work-related musculoskeletal disorder in these technicians.

Objectives: To investigate the prevalence of the work-related musculoskeletal disorder in defence personnel involved in electrical and electronic maintenance and repairs.

Methods: A cross-sectional study was carried out for 3 years, in electrical, telecom and instrument defence technicians $(\mathrm{N}=164$ ). Prevalence of work-related musculoskeletal disorder was assessed using the Nordic Musculoskeletal Questionnaire. Effect of age, working hours, work experience, Basal metabolic index and type of job on the prevalence of work-related musculoskeletal disorder was investigated using logistic regression analysis. Results: A total of 119 (72.56\%) respondents reported work-related musculoskeletal disorder with 53.04\% multiples \& $19.51 \%$ single work-related musculoskeletal disorder. Simultaneous presence of neck, shoulder and upper back work-related musculoskeletal disorder were observed. Highest rate of work-related musculoskeletal disorder was in neck (44.44\%), followed by shoulder (27.16\%), ankle/ foot (14.81\%), elbow/ forearm (12.96\%), low back $(11.72 \%)$ and wrist/ finger (9.87\%). Neck (44\%) related work-related musculoskeletal disorder were highest across all job crafts. Work experience $(p=0.012$; OR $=0.87 ; 95 \% \mathrm{Cl}-0.78-0.97)$, working hours $(p=0.031$; $\mathrm{OR}=1.73,95 \% \mathrm{Cl}-0.58-5.12)$ smoking $(\mathrm{p}=0.00 ; \mathrm{OR}=5.3,95 \% \mathrm{Cl}=4.3-8.48)$ and job crafts like electrician $(p=0.434 ; \mathrm{OR}=1.89,95 \% \mathrm{Cl}=1.08-3.31)$ and telecom mechanics $(p=0.026 ; \mathrm{OR}=1.26,95 \% \mathrm{Cl}=0.74-2.15)$ were significantly associated as risk factors of work-related musculoskeletal disorder.

Conclusion: High prevalence of work-related musculoskeletal disorder was observed in electrical, telecommunication \& instrument mechanics, with higher multiple work-related musculoskeletal disorder. Working hours, work experience, job craft and smoking were highly associated with a work-related musculoskeletal disorder. We suggest suitable ergonomic intervention and awareness program along with smoking control drive to reduce the risk of work-related musculoskeletal disorder.

Key words:- Defence, Maintenance workers, Musculoskeletal Disorder, Smoking, Working hour.

DOI: https://doi.org/10.3126/ijosh.v10i1.29878

\section{Introduction}

W ork-related musculoskeletal disorders (WMSDs) covers a big umbrella of inflammatory and degenerative disorders affecting soft tissues and

Date of submission: 20.02.2020

Date of acceptance: 16.05.2020

\section{Corresponding Author}

Roli Dave

E 503 Jalvayu Vihar Sector A, Hiranandani Garden, Powai Mumbai

9819153860

E-mail: drroli.dave@gmail.com skeletal structures, that are initiated or aggravated by work or it's related settings. ${ }^{1-2}$ MSDs have the potential of developing into serious injuries, if not timely intervened. They are the major causes of pain, discomfort, disability, absenteeism, reduced productivity, and heavy financial costs among workers worldwide. ${ }^{3,4}$ It has become the most expensive form of work disability. ${ }^{5}$ As reported by Yasobant \& Rajkumar (2014), the estimated cost of WMSDs

\section{c) (7) (8)}

This journal is licensed under a Creative Commons AttributionNon Commercial 4.0 International License. 
was approximately 215 billion dollars in 1995 in the United States ${ }^{6} ; 26$ billion Canadian dollars in 1998 in Canada, and 38 billion Euros in 2002 in Germany. ${ }^{7}$ The economic cost of work-related injury and illness was estimated to be $4 \%$ of Gross domestic product (GDP) of developing countries In India too, WMSDs is one of the major occupational health problems and amounts to about $40 \%$ of total costs incurred for work-related injuries. ${ }^{6}$

Electricians, telecommunication and computer professionals suffer from neck, upper back and upper limb WMSDs. Literature shows a high prevalence of WMSDs in electricians, call-centre workers, cable technicians, shoe factory workers, garment manufacturing workers, and similar other jobs, which require handwork, fine dexterity work and long sitting hours. $^{9-16}$

In defence, equipment exploitation is higher due to continuous training and exercises. Electricians, telecommunication and instrument technicians of defence forces play a dual role of solider and craftsman. They repair \& calibrate electrical, telecommunication and optical sub-system fitted on military equipment / vehicle. This exposes them to risk factors of manual material handling, work pressure, wrong postures, inappropriate work-station design and vibrations, causing WMSDs. ${ }^{17-18}$ Few literature reports describe the presence of musculoskeletal injuries in defence services, but there is a dearth of studies identifying the cause and risk factors. ${ }^{19}$ We had identified certain job task risk factors for WMSDs in heavy engineering mechanics. ${ }^{20}$ Even so, the literature lacks insight about the MSDs in defence personnel, involved in light engineering maintenance and repair operation along with combat duties and military training.

Considering the dearth of knowledge available in the literature regarding WMSD in defence electrical and electronic maintenance workers. This study aims to investigate the prevalence of WMSDs in defence personnel involved in electrical and electronic maintenance and repairs. We found a high prevalence of WMSDs in defence maintenance personnel dealing with electrical, electronic and instrument repair. Neck and Shoulder discomfort were the commonest complaints.

\section{Methods}

A cross-sectional survey study was conducted on defence personnel involved in electrical, electronic and instrument repair and maintenance, in addition to their combat role. Seven different geographic locations were chosen for the survey and were categorized as: (i) Plains (Coastal region) (ii) High Altitude \& Hilly (North-Eastern region) (iii) Semi-desert (North-Western region).

Six senior level officers (two from each geographical terrain) were interviewed, to understand the technical qualification, role, responsibilities and job content of this personnel. They have job profiles, based on their expertise, ranks/seniority and years of service. Personnel having $\geq 15$ years of service may get promoted and have more of supervisory roles with some execution role (G1), whereas those with $<15$ years of service, are of lower rank and executers of maintenance/repair task (G2). Table 1 summarizes various trades of maintenance forces. The task of these three job crafts is relatively similar, involving light engineering work.

A total of 211 defence personnel involved in a variety of electrical, telecommunication and instrument maintenance tasks were enrolled for the study, after obtaining informed consent. The respondents were assured about the confidentiality of the information and its use for academic research. A total of 47 personnel were excluded - 34 due to incomplete information, seven due to previous injuries, five due to recent viral illness like dengue \& chikungunya and one due to ankylosing spondylitis with positive Human Leucocyte Antigen (HLA) B27. The final number was 164 - a response rate of $77.73 \%$.

All the respondents filled the questionnaire having Part 'A'. with three sections: (i) Personal information (ii) Medical history (iii) Miscellaneous information (hobbies, habits, lifestyle etc.) and Part ' $\mathrm{B}$ ' as Nordic Musculoskeletal Questionnaire (NMQ). ${ }^{21}$ Respondents were thoroughly briefed, as to how to fill the questionnaire. Data of age, work duration, work experience, body mass index (BMI) and smoking was extracted out of part ' $A$ '. The presence of MSDs was defined as an ache, pains or discomfort in any of the eight body regions marked in body chart. (Figure1). The aches and pain in the head and stomach were excluded, as they could be related to systemic illness.

The case definition of musculoskeletal symptoms is taken similar to National Institute of Occupational Safety and Health (NIOSH) ${ }^{22}$ and is (i) the subject who felt musculoskeletal symptom in last 12 months in any 
of the body parts (ii) the symptoms that lasted for more than seven days at a stretch or it was felt for more than once in a month. MSDs due to non-occupational causes such as a motor accident or sports activities were excluded. To avoid the recall bias, the MSDs were restricted to the past one year. The period of investigation was from 14 Mar 2015 to 3 Oct 2018 at different geographic locations in India, where the investigator travelled and collected the data. This study was approved for ethical consideration by the research review committee of Sunandan Devatia School of Science, NMIMS Mumbai.

\section{Statistical methods}

Descriptive statistical analysis of demographic details including age, BMI, employment duration, working hours, smoking, job content, body parts affected, and MSD prevalence were done. Logistic regression was carried out to ascertain the relationship between the independent variable and dependent variable. The level of significance was set to a standard value of 0.05 with a confidence interval of $95 \%$. The demographic variables: age, BMI, work experience, working hours and other variables like smoking and job contents were classified as independent, whereas MSDs prevalence was taken as dependent variables.

The general logistic regression model for $p$ number of predictors is given by

$=\beta_{0}+\beta_{1} x_{1}+\beta_{2} x_{2}+\beta_{3} x_{3}+\beta_{4} x_{4}+\ldots \ldots .+\beta_{p} x_{p}$

Where $x$ denotes log odd ratio of MSD, and $\beta_{1}, \beta_{2}, \ldots$. etc are regression coefficient for $p$ variable of interest.

Equation (1) is used to formulate logistic models to examine the effect of various independent variables on WMSDs prevalence (dependent).

\section{Results}

Table 3 presents the descriptive analysis of age, work experience, BMI, work duration in various Job crafts. Mechanics were in the age group of 21-45 years with a mean age of 32.25 years. Mean work experience was 13.97 years (range: 1-25 years), with instrument mechanics having maximum work experience (15.56 years), followed by telecom operators (14.65 years) and electrician (11.61 years). Work experience and age of subjects matched each other. Work duration for telecom mechanics and instrument mechanics is nearly the same (10.02 hours/day and 10.69 hours/day respectively) and that of an electrician is 8.49 hours/ day. The mean BMI of the total sample was $27.30 \mathrm{~kg} / \mathrm{m}^{2}$ (range: $20.80-33.7 \mathrm{~kg} / \mathrm{m}^{2}$ ) with instrument mechanics having highest mean BMl of $28.53 \mathrm{~kg} / \mathrm{m}^{2}$ followed by telecom mechanics $\left(27.88 \mathrm{~kg} / \mathrm{m}^{2}\right)$ and electrician $\left(25.03 \mathrm{~kg} / \mathrm{m}^{2}\right)$.

Pain /symptoms in one body region and more than one region is termed as single and multiple WMSDs respectively. Overall $119(72.56 \%)$ personnel reported WMSDs with 87 (53.04\%) personnel suffering from multiple WMSDs and 32 (19.51\%) from single WMSDs. Prevalence of multiple WMSDs (Table 4) was higher than Single WMSDs among all job crafts $(64.44 \%$ Vs $22.22 \%$ in an electrician, $47.91 \%$ Vs $19.79 \%$ in telecom mechanics \& $52.17 \%$ Vs $13.04 \%$ in instrument mechanics. G2 maintenance personnel in all job crafts had a higher prevalence of single WMSDs (25.43\% Vs 6\%) whereas G1 maintenance personnel reported more multiple WMSDs (56\% Vs $51.75 \%$ ). Overall G2 $(77.19 \%)$ maintenance personnel had a high prevalence of WMSDs as G1 (62\%) maintenance personnel (Figure 2).

Table 5 shows the prevalence of WMSDs in different body parts and its association with age, work experience, work duration, BMI and smoking habit. Prevalence of pain in Neck $(47.11 \%$ in younger and $38.18 \%$ in a higher aged group) was reported maximum, followed by shoulder WMSDs $(20.31 \%$ in younger and $35.71 \%$ in a higher aged group). Mechanics had increased WMSDs of the upper limb and upper back in aged group $\leq 35$ Years compared to aged group $>35$ Years (elbow/forearm: $14.89 \%$ vs $10 \%$, wrist/fingers: $27.65 \%$ vs 4.28 , upper back: 12.765 vs $7.14 \%$ ); Whereas mechanics in aged group >35 Years had a higher prevalence of low back, knee and foot/ankle $(14.28 \%$ vs $9.57 \%, 15.71 \%$ vs $9.31 \%$, $18.57 \%$ vs $11.70 \%$ respectively). Personnel having work-experience $\leq 15$ years reported higher WMSDs in neck (45.61\% Vs $40 \%)$, elbow/forearm $(14.03 \%$ Vs $10 \%$ ), upper back (12.28\% Vs $6 \%$ ) and wrist/ fingers $(10.52 \% \mathrm{Vs} 4 \%)$. On the other hand, WMSDs in the low back ( $16 \%$ Vs $9.65 \%)$, Knee (20\% Vs $6.14 \%$ ), shoulder (46\% Vs $18.4 \%)$ and foot/ ankle (22\% Vs $11.40 \%)$ were reported more in mechanics with $>15$ years of work experience. The alarming prevalence of neck and shoulder WMSDs were seen in all. The prevalence of WMSDs in the low back, knee, shoulder and foot/ ankle was higher in personnel working for 10 hours/ day, while neck WMSDs was higher in all irrespective of working hours. Overweight maintenance personnel 
BMI ( $\geq 25 \mathrm{~kg} / \mathrm{m} 2$ ) had a high prevalence of neck, knee, shoulder, foot/ ankle WMSDs. Personnel who smoke reported higher WMSDs in all body regions.

Table 6 represents a matrix with a prevalence of WMSDs in various body regions and different job crafts. The maintenance personnel reported high rate of WMSDs in neck $(44.44 \%)$ and shoulder $(27.16 \%)$ followed by ankle/ foot (14.81\%), Elbow/ forearm $(12.96 \%)$, low back $(11.72 \%)$ and wrist/ finger $(9.87 \%)$. Neck related WMSDs were highest across all job crafts. G1 Electricians reported the highest prevalence of low back $(36.36 \%)$ and shoulder $(45.45 \%)$ symptoms, whereas G2 electrician reported high neck (50\%) wrist/ finger (26.47\%) WMSDs. Both $\mathrm{G} 1$ and $\mathrm{G} 2$ telecom mechanics reported very high neck $(38.23 \%$ \& $46.77 \%$ respectively) and shoulder $(44.11 \%$ \& $43.7 \%$ respectively) WMSDs. G2 Telecom mechanics had higher upper-back (16.13\% Vs $2.94 \%$ ) and elbow/ forearm $(12.9 \%$ Vs $5.88 \%)$ symptoms, as compared to $\mathrm{G} 1$ Telecom mechanics. Ankle/foot WMSDs were reported highest in $\mathrm{G} 1$ instrument mechanics (40\%) and second highest in G1 Telecom mechanics (20.58\%). G1 instrument mechanics had highest prevalence of neck (60\%), shoulder (60\%), elbow/ forearm $(20 \%)$ and wrist/ fingers (40\%) WMSDs. Except for neck symptoms, WMSDs in all body regions had equal distribution in $\mathrm{G} 2$ instrument mechanics.

\section{Logistic Regression}

We carried out logistic regression analysis on respondents, using age, work experience, $\mathrm{BMI}$, working hour, smoking and Job crafts as independent variable and WMSDs as a dependent variable. We derived four models (M1 -M4) to explain the effect of demographic characteristics (age, work experience, BMI), working hour, smoking habits and various job crafts on WMSDs. E.g., Model 1 (M1) has demographic variables (Age, $\mathrm{BMI}$, work experience) as an independent variable and is represented in mathematical terms as:

$\log \left(\pi(x) / 1-\pi(x)=\beta 0+\beta_{\text {Age }} x_{\text {Age }}+\beta_{\text {BMI }} x_{\text {BMI }}+\beta_{w} x_{w}\right.$ Where ' $w$ ' denotes work experience.

M2, M3 and M4 are similar mathematical equations; where daily working hour is the independent variable for M2, Smoking for M3 and Job crafts for M4. All six job crafts were examined for its effect on WMSDs. Table 7 and Table 8 describes the summary of logistic regression. It indicates independent variable of each model $\beta$ - coefficient of independent $p$ value, odds ratio and $95 \%$ confidence interval of odds ratio.

Statistically significant results were obtained for work experience $(\mathrm{OR}=0.87,95 \% \mathrm{Cl}=0.78-0.97)$, working hours $(\mathrm{OR}=1.73,95 \% \mathrm{Cl}=0.58-5.12)$, smoking $(\mathrm{OR}=$ $5.52,95 \% \mathrm{Cl}=3.43-8.48$ ) (Table 7 ) and job crafts (Table 8) like Electricians (for G1 OR=1.89, 95\% $\mathrm{Cl}=1.08-3.31$; for $\mathrm{G} 2 \mathrm{OR}=2.19,95 \% \mathrm{Cl}=1.51-3.16$ ) and Telecom mechanics(for $\mathrm{G} 1 \mathrm{OR}=1.26,95 \% \mathrm{Cl}=$ 0.74-2.15; for $\mathrm{G} 2 \mathrm{OR}=1.27,95 \% \mathrm{Cl}=0.56-2.91$ ). Electricians had twice the probability of developing WMSDs as compared to other job crafts (Table 8). Similarly, smokers had more that $500 \%$ chance of developing WMSDs (Table 7).

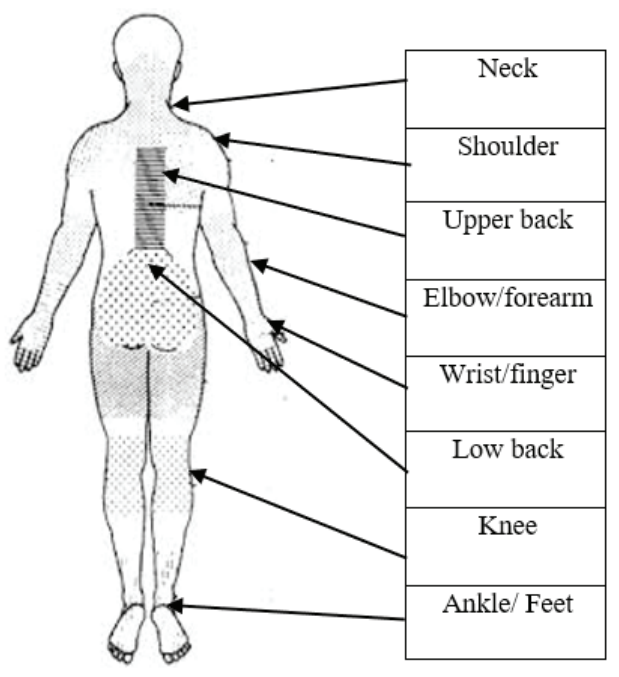

Figure 1: NMQ Body Chart ${ }^{21}$ 

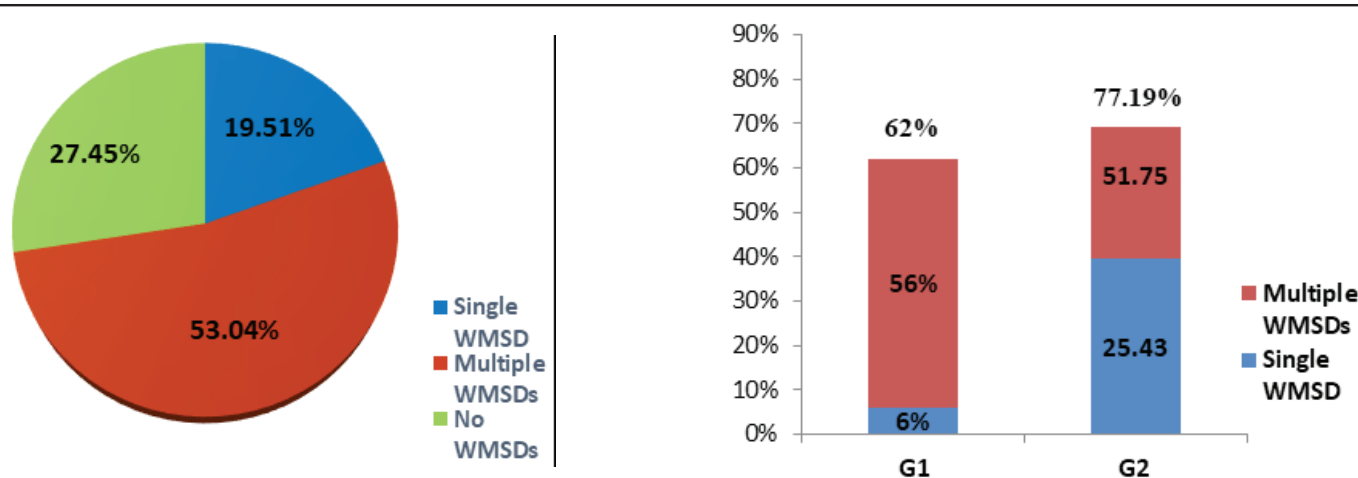

Figure 2: Distribution of Single and Multiple WMSDs in Light Engineering Maintenance Defence Personnel

Table 1: Description of Various Job craft of Light Engineering Maintenance Defence Personnel

\begin{tabular}{cll}
\hline S.N. Job Crafts & Job Description \\
\hline \multirow{3}{*}{$\begin{array}{l}\text { Electrician } \\
\text { Repair and Maintenance of electrical components and subsystems, automobile, }\end{array}$} \\
& $\begin{array}{l}\text { generators, construction machinery like Dozer, compressors etc. The task involves } \\
\text { working on a test bench or in-situ repair, having constricted space, bearing awkward } \\
\text { posture for a long duration. }\end{array}$ \\
& $\begin{array}{l}\text { Repair of communication equipment, radar systems and computers subsystems. } \\
\text { Telecom Mechanic }\end{array}$ & $\begin{array}{l}\text { Task majorly involves working on a test bench for long duration and use of } \\
\text { magnifying glasses and small toolsets for the repair of Printed Circuit board. }\end{array}$ \\
& Instrument & $\begin{array}{l}\text { Repair, maintenance and calibration of optical devices, dial gauges, digital interfaces } \\
\text { of range measuring equipment. The task involves working on a test bench and } \\
\text { adjustment of optical sight. }\end{array}$ \\
\hline
\end{tabular}

Table 2: Geographical location-based Zonal Distribution

\begin{tabular}{lccc}
\hline Geographical Region & Group 1 (G1) & Group 2 (G2) & Total \\
\hline Plains (coastal region) & 17 & 32 & 49 \\
High Altitude \& Hilly (North- Eastern region) & 15 & 28 & 43 \\
Semi - desert (North-Western region) & 18 & 54 & 72 \\
Total & $\mathbf{5 0}$ & $\mathbf{1 1 4}$ & $\mathbf{1 6 4}$ \\
\hline
\end{tabular}

Table 3: Demographic Data of Different Job Crafts in Light Engineering Maintenance Defence Personnel

\begin{tabular}{lcccc}
\hline Job Crafts & $\begin{array}{c}\text { Age (Years) } \\
\text { Mean (SD) }\end{array}$ & $\begin{array}{c}\text { Work Experience } \\
\text { (Years) } \\
\text { Mean (SD) }\end{array}$ & $\begin{array}{c}\text { BMI } \\
\text { (kg/m }{ }^{2} \text { ) } \\
\text { Mean (SD) }\end{array}$ & $\begin{array}{c}\text { Working Hours } \\
\text { (hours/day) } \\
\text { Mean (SD) }\end{array}$ \\
\hline Electrician & $27.67(5.04)$ & $11.61(2.54)$ & $25.03(1.55)$ & $8.49(1.02)$ \\
Telecom Mech & $32.79(5.44)$ & $14.65(2.62)$ & $27.88(1.35)$ & $10.02(1.34)$ \\
Instrument Mech & $38.60(6.39)$ & $15.56(1.68)$ & $28.53(1.16)$ & $10.69(1.14)$ \\
Total & $\mathbf{3 2 . 2 5 ( 6 . 3 9 )}$ & $\mathbf{1 3 . 9 7 ( 3 . 3 3 )}$ & $\mathbf{2 7 . 3 0 ( 2 . 0 6 )}$ & $\mathbf{9 . 7 0 ( 1 . 6 2 )}$ \\
\hline
\end{tabular}

Table 4: Single Vs Multiple WMSDs in Various Job Crafts of Light Engineering Maintenance Defence

\begin{tabular}{lccc}
\hline Job Crafts & Single WMSDs & Multiple WMSDs & \multicolumn{2}{c}{ Total WMSDs } \\
$(\mathbf{N i})$ & $\mathbf{n ~ ( \% )}$ & $\mathbf{n}(\%)$ & $\mathbf{n}(\%)$ \\
\hline G1 Electrician (11) & $1(9.09)$ & $8(72.72)$ & $9(81.81)$ \\
G2 Electrician (34) & $9(26.47)$ & $21(61.76)$ & $30(88.23)$ \\
Total Electrician (G1+G2) & $10(22.22)$ & $\mathbf{2 9 ( 6 4 . 4 4 )}$ & $\mathbf{3 9 ( 8 6 . 6 6 )}$ \\
G1 Telecom Mechanic (34) & $2(5.88)$ & $17(50)$ & $19(55.88)$ \\
G2 Telecom Mechanic (62) & $17(27.41)$ & $29(46.77)$ & $46(74.19)$ \\
Total Telecom Mechanic (G1+G2) 96 & $\mathbf{1 9 ( 1 9 . 7 9 )}$ & $\mathbf{4 6 ( 4 7 . 9 1 )}$ & $\mathbf{6 5 ( 6 7 . 7 0 )}$
\end{tabular}


Table 4 cont ...

G1 Instrument Mechanic (5)

$3(16.66)$

$3(60)$

$3(60)$

G2 Instrument Mechanic (18)

3 (13.04)

$9(50)$

$12(66.66)$

Total Instrument Mechanic (G1+G2) 23

32(19.51)

$12(52.17)$

$15(65.21)$

Total (164)

87 (53.04)

119 (72.56)

Table 5: Association of WMSDs with Personal Characteristics of Light Engineering Maintenance Defence Personnel

\begin{tabular}{|c|c|c|c|c|c|c|c|c|}
\hline $\begin{array}{l}\text { Personal Body Region } \\
\text { Characteristics }(\mathrm{n})\end{array}$ & $\begin{array}{c}\text { Low } \\
\text { Back (\%) }\end{array}$ & $\begin{array}{c}\text { Neck } \\
(\%)\end{array}$ & $\begin{array}{c}\text { Knee } \\
(\%)\end{array}$ & $\begin{array}{c}\text { Shoulder } \\
(\%)\end{array}$ & $\begin{array}{l}\text { Foot I } \\
\text { Ankle } \\
(\%)\end{array}$ & $\begin{array}{l}\text { Elbow } \\
\text { /Forearm } \\
(\%)\end{array}$ & $\begin{array}{l}\text { Upper } \\
\text { Back } \\
(\%)\end{array}$ & $\begin{array}{c}\text { Wrist/ } \\
\text { Finger } \\
(\%)\end{array}$ \\
\hline \multicolumn{9}{|l|}{ Age } \\
\hline$\leq 35$ Years $(94)$ & 9.57 & 47.87 & 9.31 & 20.21 & 11.70 & 14.89 & 12.76 & 27.65 \\
\hline$>35$ Years $(70)$ & 14.28 & 38.57 & 15.71 & 35.71 & 18.57 & 10 & 7.14 & 4.28 \\
\hline \multicolumn{9}{|l|}{ Work Experience } \\
\hline$\leq 15$ Years (92) & 9.65 & 45.61 & 6.14 & 18.4 & 11.40 & 14.03 & 12.28 & 10.52 \\
\hline$>15$ Years $(72)$ & 16 & 40 & 20 & 46 & 22 & 10 & 6 & 4 \\
\hline \multicolumn{9}{|l|}{ Working Hours } \\
\hline Up to 8 (47) & 7.02 & 48.93 & 10.83 & 17.02 & 6.38 & 23.40 & 17.02 & 21.27 \\
\hline$>8-10(70)$ & 4.28 & 41.42 & 4.28 & 17.14 & 15.71 & 8.57 & 10 & 2.85 \\
\hline$>10(47)$ & 17.02 & 42.55 & 21.27 & 44.68 & 21.27 & 8.51 & 4.25 & 4.25 \\
\hline \multicolumn{9}{|l|}{ BMI } \\
\hline$<25(23)$ & 16.66 & 37.5 & 9.52 & 12.5 & 4.16 & 20.83 & 8.33 & 33.33 \\
\hline $25-29.99(125)$ & 11.29 & 45.16 & 11.29 & 25.80 & 16.93 & 11.29 & 11.29 & 4.83 \\
\hline$\geq 30$ (16) & 6.25 & 43.75 & 6.25 & 31.25 & 12.5 & 12.5 & 12.5 & 0 \\
\hline \multicolumn{9}{|l|}{ Smoking } \\
\hline Yes (59) & 17.39 & 45.76 & 23.72 & 59.32 & 20.33 & 27.11 & 2.20 & 16.94 \\
\hline No (105) & 6.66 & 42.85 & 2.85 & 8.75 & 11.42 & 4.76 & 3.78 & 3.80 \\
\hline
\end{tabular}

' $n$ ' denotes total number of respondents in specific intervals

Table 6: Job Crafts Associated with Body Region-wise WMSDs Among Light Engineering Maintenance Defence Personnel

\begin{tabular}{|c|c|c|c|c|c|c|c|c|c|}
\hline $\begin{array}{l}\text { Body } \\
\text { Region } \\
\text { Craft }\left(\mathrm{N}_{\mathrm{j}}\right)\end{array}$ & $\begin{array}{l}\text { Low } \\
\text { Back } \\
(\%)\end{array}$ & $\begin{array}{l}\text { Neck } \\
(\%)\end{array}$ & $\begin{array}{l}\text { Knee } \\
(\%)\end{array}$ & $\begin{array}{c}\text { Shoulder } \\
\text { (\%) }\end{array}$ & $\begin{array}{c}\text { Ankle/ } \\
\text { Foot } \\
(\%)\end{array}$ & $\begin{array}{l}\text { Elbow/ } \\
\text { forearm } \\
(\%)\end{array}$ & $\begin{array}{c}\text { Upper } \\
\text { back } \\
(\%)\end{array}$ & $\begin{array}{c}\text { Wrist/ } \\
\text { Finger } \\
(\%)\end{array}$ & $\begin{array}{c}\text { MSD } \\
\text { Prevalence } \\
\mathbf{n}\end{array}$ \\
\hline G1Electrician (11) & 36.36 & 36.36 & 0 & 45.45 & 18.18 & 18.18 & 9.09 & 9.09 & 19 \\
\hline G2 Electrician (34) & 11.76 & 50 & 5.88 & 14.7 & 8.82 & 17.64 & 5.88 & 26.47 & 48 \\
\hline $\begin{array}{l}\text { G1 Telecom } \\
\text { Mechanic (34) }\end{array}$ & 8.82 & 38.23 & 26.47 & 44.11 & 20.58 & 5.88 & 2.94 & 2.94 & 51 \\
\hline $\begin{array}{l}\text { G2 Telecom } \\
\text { Mechanic (62) }\end{array}$ & 8.06 & 46.77 & 4.83 & 43.75 & 12.90 & 12.90 & 16.13 & 3.22 & 79 \\
\hline $\begin{array}{l}\text { G1 Instrument } \\
\text { Mechanic (5) }\end{array}$ & 20 & 60 & 20 & 60 & 40 & 20 & 20 & 40 & 14 \\
\hline $\begin{array}{l}\text { G2 Instrument } \\
\text { Mechanic (18) }\end{array}$ & 11.11 & 33.33 & 11.11 & 11.11 & 11.11 & 11.11 & 11.11 & 5.55 & 19 \\
\hline $\begin{array}{l}\text { Total Frequency of } \\
\text { Occurrence N=164 } \\
(\%)\end{array}$ & 11.72 & 44.44 & 10.49 & 27.16 & 14.81 & 12.96 & 10.49 & 9.87 & 230 \\
\hline
\end{tabular}

$\mathrm{Nj}$ denotes a total number of participants of specific job craft 
Table 7: Logistic Model Derived Odd Ratio for Prevalence of WMSDs in Light Engineering Maintenance Defence Personnel $(\mathrm{N}=164)$

\begin{tabular}{|c|c|c|c|c|c|c|}
\hline \multirow{2}{*}{ Model } & \multirow{2}{*}{ Parameters } & \multirow{2}{*}{ Coefficient } & \multirow{2}{*}{$P$ value } & \multirow{2}{*}{$\begin{array}{c}\text { Odds Ratio } \\
\text { (OR) }\end{array}$} & \multicolumn{2}{|c|}{$95 \% \mathrm{Cl}$} \\
\hline & & & & & Lower & Upper \\
\hline \multirow{3}{*}{ M1 } & Age (Years) & $-0,04027$ & 0.144 & 0.46 & 0.91 & 1.01 \\
\hline & Work Experience & -0.13904 & $0.012^{*}$ & 0.87 & 0.78 & 0.97 \\
\hline & $\mathrm{BMI}$ & 0.1140 & 0.182 & 1.12 & 0.95 & 1.33 \\
\hline M2 & Working Hours & 0.60541 & $0.031^{*}$ & 1.73 & 0.58 & 5.12 \\
\hline M3 & Smoking & 1.7075 & $0.000^{*}$ & 5.52 & 3.43 & 8.48 \\
\hline
\end{tabular}

*Values indicates statistically significant $\beta$ coefficient, $\mathrm{Cl}$ is confidence interval

Table 8: Impact of Job Craft on Prevalence of WMSDs in Light Engineering Maintenance Defence Personnel

\begin{tabular}{|c|c|c|c|c|c|c|}
\hline \multirow{2}{*}{ Model } & \multirow{2}{*}{ Job Craft } & \multirow{2}{*}{ Coefficient } & \multirow{2}{*}{$P$ value } & \multirow{2}{*}{$\begin{array}{c}\text { Odds Ratio } \\
\text { (OR) }\end{array}$} & \multicolumn{2}{|c|}{$95 \% \mathrm{Cl}$} \\
\hline & & & & & Lower & Upper \\
\hline \multirow{6}{*}{ M 4} & G1 Electrician & 0.9760 & $0.041^{*}$ & 1.89 & 1.08 & 3.31 \\
\hline & G2 Electrician & 0.8640 & $0.034^{*}$ & 2.19 & 1.51 & 3.16 \\
\hline & G1 Telecom Mechanic & 0.5413 & $0.026^{*}$ & 1.26 & 0.74 & 2.15 \\
\hline & G2 Telecom Mechanic & 0.8721 & $0.046^{*}$ & 1.27 & 0.56 & 2.91 \\
\hline & G1 Instrument Mechanic & -0.0195 & 0.383 & 0.98 & 0.94 & 1.02 \\
\hline & G2 Instrument Mechanic & 0.0321 & $0.0271^{*}$ & 1.04 & 0.97 & 1.11 \\
\hline
\end{tabular}

*Values indicates statistically significant $\beta$ coefficient, $\mathrm{Cl}$ is confidence interval

\section{Discussion}

Combat forces generally get all the highlights and importance and are given more weightage by the society and system. Literature reveals that studies are only done on them, relating their stress and occupational issues. ${ }^{14,19,23-28}$ Indian defence uses longranged, high definition optical devices, high-tech and complex machinery and equipment, having electronic and electrical interfaces. The electrician, telecom, and instrument maintenance experts in defence must provide round the clock support of maintenance and repair of these equipment, posturing them to occupational stress like high work-stress, time pressure due to urgency, workload, work intensity. They are also exposed to other ergonomic stressors such as difficult working posture, inappropriate workstations, long working hours and organisational stressors. We found high prevalence WMSDs $(72.56 \%)$ in these defence maintenance workforces, which is highest so far in any defence reportings. ${ }^{25,29-31}$

High prevalence of multiple WMSDs (53.04\%) was noted as compared to single WMSDs (19.51\%). Neck and shoulder WMSDs were high across all job crafts Most mechanics who reported shoulder or upper back WMSDs also reported neck symptoms. This is probably due to their working postural requirement to flex their neck and lean forward for long hours while working on test bench or while doing in-situ repair of any subsystem of any machinery/equipment. Neck flexed posture of 30 degrees or above increases the neck extensor fatigue rates ${ }^{32}$ and time spent in forward neck flexion (even in angle of $15^{\circ}$ ) is significantly associated with neck and neck/shoulder disorders. ${ }^{33}$ Constrained working postures, long working hours with arms at shoulder height and repetitive work tasks, associated with light engineering maintenance are risk-factors of shoulder and trapezius pathology. ${ }^{34} \mathrm{G} 1$ electrician reported highest incidence of low-back and knee pain. This is likely due to cumulative effect of agerelated degenerative changes and working postural faults. It was observed that they work for long hours in flexed spine posture, while leaning over vehicle to repair electrical faults.

These; over years of work can create structural faults in spine, resulting into chronic back pain. Electrician also work in squat position while tackling vehicle circuit wiring and lights. Electricians, mainly G2 are skilled with fine dexterity in rolling screwdriver and use of mini tool. They use increased grip strength while turning heavy levers or knobs to lift the repairable part out of machinery. They reported increased incidence of wrist/ finger symptoms. Four of them suffered chronic carpaltunnel syndrome, two with small joint pains and three with collateral ligament strains. All three-instrument 
mechanics had De Quervains syndrome. Both G1 and $\mathrm{G} 2$ electricians reported high elbow/forearm pain. Combination of medial and lateral epicondylitis existed, and many complained of pain spreading to arm and forearm. Telecom mechanics reported more ankle symptoms. They usually have a sitting job and so we couldn't relate it to their job craft speciality. Either this was due to previous injuries ( $>3$ months old, as this was the inclusion criteria) or related to their combat training.

Results of logistic regression revealed a positive correlation between daily working-hours and negative correlation with work-experience. Because of their dual role, these mechanics are responsible for the security of their area. Apart from technical work, they undergo daily physical training. All this exposes them to high working hours, a risk factor to WMSDs as stated by many in literature. ${ }^{32,35-37}$ Mechanics with more work experience learn by practice and experience about ergonomic faults and they try correcting them to a certain extent. Also, more experienced personnel were from the G1 group, who mainly have a supervisory role and less executory role. They have reported comparatively less neck and shoulder symptoms, which amounts to a maximum reported WMSDs.

Smoking is very common in defence and is being taken as a social necessity while being with the peer. Some get addicted to smoking for managing stress. Smokers have 5.5 times chance of developing WMSDs. A strong positive correlation between smoking risk and WMSD prevalence is seen. Similar results were reported in past. ${ }^{25,38}$ Smoking affects the immune system and harms tissue healing. ${ }^{39}$ Some intervention or campaign to address this issue and to reduce smoking habit is strongly advocated as it is a modifiable risk-factors that can reduce the prevalence of MSDs if addressed. ${ }^{7}$

All Job crafts, except G1 instrument mechanics, had statistically significant correlation to WMSDs, however strong correlation was only seen in an electrician. Though all had similar work duration, training and exercise schedule and other ergonomic risks, the electrician had a more difficult job involving awkward posture.

We observed that the light-engineering maintenance personnel at times work with insufficient illumination, which is also a risk-factor of WMSDs. ${ }^{41}$ They use torch lights or draw power from the vehicle engine while working in dark or night-time. This provision is insufficient while they work with circuits which are situated deeper in huge equipment. This poses them to eyestrain, subsequently headache and neck strain, as explained by senior officers.

Though we collected data from seven locations in India, we could survey only 164 light engineering defence maintenance personnel. This is because the ratio of them in comparison with other tradecrafts is less. A similar study on even large sample size covering more locations will throw better insight into job craft association and WMSDs. The odds ratio of Job craft may improve and so such study is suggested. Inclusion of pain and discomfort rating can bring out the actual depth of suffering. There may be some amount of recall bias.

Most work, relating WMSDs and defence is common in combat forces and training, addressing training methods, uniforms, shoes, organisational stress, workload. ${ }^{23,28,42}$ We had done a detailed literature review $^{20}$ and to our knowledge, this is first study to link WMSDs in defence electrician, telecom mechanics and instrument mechanics, especially in the Indian scenario.

\section{Conclusion}

Our study provides detailed epidemiological data on WMSDs among light-engineering mechanics electrical of Indian defence forces. Neck, shoulder and upper back were most affected areas and associated with each other, increasing prevalence of multiple WMSDs. Less work-experience increased daily working hours, smoking habit and different job-crafts (electrician, instrument and telecom mechanics) were found to be associated risk-factors. Occupational risk-factors like workload, urgency, organisational policies, training, awkward posture, constraint workspace, long working hours, shift duties, and poor illumination might lead to many WMSDs in these personnel. We recommend the inclusion of proper screening methods and appropriate intervention strategies by authorities to reduce the incidence of WMSDs. Experimental studies on prevention, intervention and their benefits are recommended. 


\section{References}

1. Cihan A, Esen H, FigA, Yılmaz MK. Image processingaided working posture analysis: I-OWAS. Comput Ind Eng. 2015;85:384-94.

2. da Costa BR, Vieira ER. Stretching to reduce workrelated musculoskeletal disorders: A systematic review. J Rehabil Med. 2008;40(5):321-8.

3. Kristy N. Carlisl AWP. Psychological Distress and Pain Reporting in Australian Coal Miners. Saf Health Work [Internet]. 2014;5(4):203-9. Available from: http://dx.doi.org/10.1016/j.shaw.2014.07.005

4. Bhattacharya A. Costs of occupational musculoskeletal disorders (MSDs) in the United States. Int J Ind Ergon [Internet]. 2014;44(3):44854. Available from: http://dx.doi.org/10.1016/j. ergon.2014.01.008

5. Gertrud Breindl. Annual Activity Report 2017. Eur Agency Saf Heal Work. 2016;1-130.

6. Yasobant S, Rajkumar P. Work-related musculoskeletal disorders among health care professionals: A cross-sectional assessment of risk factors in a tertiary hospital, India. Indian J Occup Environ Med. 2014;18(2):75.

7. Yasobant S, Rajkumar P. Work-related musculoskeletal disorders among health care professionals: A cross-sectional assessment of risk factors in a tertiary hospital, India. Indian J Occup Environ Med [Internet]. 2014;18(2):75. Available from: http://www.ijoem.com/text.asp?2014/18/2/75/146896

8. Yong E. Global Estimates of Occupational Accidents and Work-related IIInesses 2014. 2014;

9. Padmanathan V, Joseph L, Omar B NR. Prevalence of Musculoskeletal Disorders and Related Occuaptional Causative Factors Among Electricity Linemen: A Narrative Review. Int J Occup Med Enviormental Heal. 2016;29(5):725-34.

10. Karsh B-T, Haner U-E, Kelter J, Bauer W, Rief S. Ergonomics and Health Aspects of Work with Computers [Internet]. Vol. 5624, Lecture Notes in Computer Science. 2009. 39-48-48 p. Available from: http://www.springerlink.com/content/ j687vk6hw3n6g35x/

11. Costa J S, Baptista JS, Vaz. Incidence and prevalence of upper-limb work related musculoskeletal disorders: A systematic review. Work. 2015;51(4):635-44.

12. Chattopadhyay B, Gangopadhyay P, Das A, Alam $S$, Hossain M, Chowdhury A, et al. Respiratory response to tobacco dust exposure among biddi binders: A follow up and bronchodilator study. Indian J Occup Environ Med [Internet]. 2014;18(2):57. Available from: http://www.ijoem.com/text. asp?2014/18/2/57/146891

13. Hossain MD, Aftab A, Al Imam MH, Mahmud I, Chowdhury IA, Kabir RI, et al. Prevalence of work related musculoskeletal disorders (WMSDs) and ergonomic risk assessment among readymade garment workers of Bangladesh: A cross sectional study. PLoS One. 2018;13(7):1-18.

14. Yancosek KE, Roy T, Erickson M. Rehabilitation programs for musculoskeletal injuries in military personnel. Curr Opin Rheumatol [Internet]. 2012;24(2):232-6. Available from: file:/l localhost/Users/admin/Dropbox/DrPH 20122015/DrPH - Citation Manager/DrPH Project. sente6lib/Contents/Attachments/Yancosek/2012/ Rehabilitation programs for musculoskeletal injuri. pdf\%5Cnhttp://graphics.tx.ovid.com/ovftpdfs/ FPDDNCGCBHBDCI00/fs046/ovf

15. Sen and Stanley. A Study of COmputer Related Upper Limb Discomfort and COmputer Vision Syndrome. J Hum Ergon. 2007;36(1):45-50.

16. Crawford,Laiou,Spurgeon,Mcmillan. Musculoskeletal disorders within the telecommunications sector - A systematic review. Int J Ind Ergon. 2008;38:56-72.

17. Kemp PA, Burnham BR, Copley GB, Shim MJ. Injuries to air force personnel associated with lifting, handling, and carrying objects. Am J Prev Med [Internet]. 2010;38(1 Suppl):S148-55. Available from: http://www.sciencedirect.com/science/article/pii/ S074937970900662X

18. Beer JM, Fisk AD, Rogers WA. Toward a Framework for Levels of Robot Autonomy in Human-Robot Interaction. J Human-Robot Interact [Internet]. 2014;3(2):74. Available from: http:// humanrobotinteraction.org/journal/index.php/HRI/ article/view/125

19. Mattila VM, Parkkari J, Korpela $\mathrm{H}$, Pihlajamäki $\mathrm{H}$. Hospitalisation for injuries among Finnish conscripts in 1990-1999. Accid Anal Prev. 2006;38(1):99-104.

20. Dave R, Irani A, Neekhra V. Work Related Musculoskeletal Disorders in DefencePersonnel Involvedin Heavy Engineering Maintenance. 2019; VI(294):294-304.

21. Kuorinka I, Jonsson B, KilbomA, Vinterberg H, BieringSørensen F, Andersson G, et al. Standardised Nordic questionnaires for the analysis of musculoskeletal symptoms. Appl Ergon. 1987;18(3):233-7.

22. Choi WJ, Kang YJ, Kim JY, Han SH. Symptom prevalence of musculoskeletal disorders and the effects of prior acute injury among aging male steelworkers. J Occup Health. 2009;51(3):273-82.

23. Sharma S. Occupational stress in the armed forces: An Indian army perspective. IIMB Manag Rev [Internet]. 2015;27(3):185-95. Available from: http:// dx.doi.org/10.1016/j.iimb.2015.06.002

24. Fredric Gerr, Nathan B. Fethke, Dan Anton, Linda Merlino, John Rosecrance, Michele Marcus, Emory University, Atlanta, Georgia MPJ. A Prospective Study of Musculoskeletal Outcomes Among 
Manufacturing Workers : II . Effects of Psychosocial Stress and Work Organization Factors. Hum Factors Ergon Soc. 2013;56(1):178-90.

25. Knapik JJ, Sharp MA, Canham-Chervak M, Hauret K, Patton JF, Jones BH. Risk factors for training-related injuries among men and women in basic combat training. Med Sci Sports Exerc. 2001;33(6):946-54.

26. Swedler DI, Knapik JJ, Williams KW, Grier TL, Jones BH. Risk Factors for Medical Discharge From United States Army Basic Combat Training. Mil Med. 2013;176(10):1104-10.

27. Hauret KG, Jones BH, Bullock SH, Canham-Chervak M, Canada S. Musculoskeletal injuries description of an under-recognized injury problem among military personnel. Am J Prev Med [Internet]. 2010;38(1 Suppl):S61-70. Available from: http://www.ncbi.nlm. nih.gov/pubmed/20117601

28. Nye NS, Pawlak MT, Webber BJ, Tchandja JN, Milner MR. Description and rate of musculoskeletal injuries in air force basic military trainees, 2012-2014. J Athl Train. 2016;51(11):858-65.

29. Jones $\mathrm{BH}$, Knapik JJ. Physical Training and exerse-related injures: Sureillance, Research and Injury Prevention Military Populations. Sport Med. 1999;298(0704):111-26.

30. Kaufman KR, Brodine S, Shaffer R. Military training-related injuries: Surveillance, research, and prevention. Am J Prev Med. 2000;18(3 SUPPL.):54-63.

31. Songer T. Disabilities due to injury in the military. Am J Prev Med. 2002;18(1):33-40.

32. Buckle, P.; Devereux J. Research: Work-Related Neck and Upper Limb Musculoskeletal Disorders. European Agency for Safety and Health at Work. 1999. 6-53 p.

33. Ohisson K, Attewell RG, Pålsson B, Karlsson B, Balogh I, Johnsson B, et al. Repetitive industrial work and neck and upper limb disorders in females. Am J Ind Med. 1995;27(5):731-47.

34. Hagberg M, Wegman DH. Prevalence rates and odds ratios of shoulder-neck diseases in different occupational groups. $\mathrm{Br} \mathrm{J}$ Ind Med [Internet].
1987;44(9):602-10. Available from: http://www. ncbi.nlm.nih.gov/pubmed/3311128\%0Ahttp:// www.pubmedcentral.nih.gov/articlerender. fcgi?artid=PMC1007885

35. Sanne JM. Framing risks in a safety-critical and hazardous job : risk-taking as responsibility in railway maintenance. 2008;11(5):645-57.

36. Prasun Banergee and Somnath Gangopadhyay. A Study on the Prevalence of Upper extrimity Repetetive Strain Injuries Among the Handloom Weavers of West Bengal. J Hum Ergol (Tokyo). 2003;17-22.

37. Meksawi S, Tangtrakulwanich B, Chongsuvivatwong V. International Journal of Industrial Ergonomics Musculoskeletal problems and ergonomic risk assessment in rubber tappers : A community-based study in southern Thailand. Int J Ind Ergon [Internet]. 2012;42(1):129-35. Available from: http://dx.doi. org/10.1016/j.ergon.2011.08.006

38. Morken T, B. M, T. R, O. B, L. B, S.H.V. H, et al. Prevalence of musculoskeletal symptoms among aluminium workers. Occup Med (Chic III). 2000;50(6):414-21.

39. Altarac M, Gardner JW, Popovich RM, Potter $\mathrm{R}$, Knapik JJ, Jones BH. Cigarette smoking and exercise-related injuries among young men and women. Am J Prev Med. 2000;18(3 SUPPL.):96-102.

40. Humphreys BR, Ruseski JE. An Economic Analysis of Participation and Time Spent in Physical Activity. B E J Econom Anal Policy. 2011;11(1).

41. Yenchek MR, Sammarco JJ. The potential impact of light emitting diode lighting on reducing mining injuries during operation and maintenance of lighting systems. Saf Sci [Internet]. 2010;48(10):13806. Available from: http://dx.doi.org/10.1016/j. ssci.2010.05.011

42. Madhu Sudan Pal, Deepti Majumdar, Anilendu Pramanik, Bodhisattwa Chowdhury DM. Optimum load for carriage by Indian soldiers on different uphill gradients at speci fi ed walking speed. Int J Ind Ergon [Internet]. 2014;44(2):260-5. Available from: http:// dx.doi.org/10.1016/j.ergon.2013.09.001 